\author{
ADELA ADAMUS \\ AGNIESZKA KIELKOWSKA \\ MAREK SZKLARCZYK \\ Instytut Biologii Roślin i Biotechnologii, Uniwersytet Rolniczy im. H. Kołłątaja w Krakowie \\ Kierownik Tematu: prof. dr hab. Adela Adamus Instytut Biologii Roślin i Biotechnologii, Uniwersytet \\ Rolniczy im. H. Kołłątaja w Krakowie, Al. 29 Listopada 54, 31-425 Kraków, tel. 126625188, \\ e-mail: a.adamus@urk.edu.pl
}

Prace zostały wykonane $w$ ramach badań podstawowych na rzecz postępu biologicznego $w$ produkcji roślinnej na podstawie decyzji Ministra Rolnictwa i Rozwoju Wsi nr HOR.hn.802.8.2018, Zadanie 64.

\title{
Wykorzystanie metod biotechnologicznych do poszerzenia zmienności genetycznej warzyw kapustnych
}

\author{
Biotechnological methods for broadening of the genetic diversity in brassica \\ vegetables
}

Słowa kluczowe: protoplasty, elektrofuzja, markery molekularne, androgeneza, linie DH

\author{
ZADANIE 1. OPRACOWANIE METODY OTRZYMANIA MIESZAŃCÓW \\ SOMATYCZNYCH KAPUSTY GŁOWIASTEJ (BRASSICA OLERACEA VAR. CAPITATA) \\ Z NOWYMI, WARTOŚCIOWYMI CECHAMI
}

Badania nad elektrofuzją protoplastów kapusty głowiastej prowadzone w roku 2018 wykazały, że efektywność fuzji zależała od ploidalności łączonych ze sobą protoplastów i więcej komórek ulegających połączeniu obserwowano po fuzji obiektów diploidalnych niż haploidalnych. Działanie polem elektrycznym nie wpływało negatywnie na proces regeneracji ściany komórkowej ani na żywotność protoplastów, ale miało wpływ na podziały komórkowe i obniżało aktywność mitotyczną (do 6\%) w porównaniu z kontrolą (14-21\%). Liczba rozwijających się kalusów zależała od genotypu, a w kombinacjach fuzyjnych więcej ich było po połączeniu protoplastów haploidalnych. Na pożywce regeneracyjnej otrzymane kalusy sukcesywnie tworzą pędy.

Analiza cytometryczna kalusa otrzymanego w wyniku fuzji symetrycznej wykazała różnice $\mathrm{w}$ wielkości komórek pomiędzy frakcją embriogenną i nieembriogenną. Pędy otrzymane w wyniku fuzji protoplastów haploidalnych były $2 \mathrm{n}$ lub $1 \mathrm{n}$, a otrzymane $\mathrm{w}$ wyniku fuzji protoplastów dwu obiektów diploidalnych były $4 \mathrm{x}$ lub $2 \mathrm{n}$. Ponadto 
analiza wykazała znaczny udział pędów o niezbalansowanej ploidalności, które były miksoploidami. W jądrach komórkowych kalusa pochodzącego z kultur poddanych fuzji obserwowano więcej (6-10\%) komórek z wieloma jąderkami (4-5 szt.) w porównaniu do kontroli (1-2\%). Zwiększona liczba jąderek w jądrze komórkowym może być skorelowana w wyższą ploidalnością tych komórek.

Walidacja metodyki inaktywacji genomu cytoplazmatycznego wykazała różnice w reakcji na jodoacetamid (IOA) między badanymi obiektami. W pierwszej dobie po izolacji obserwowano spadek żywotności protoplastów wraz ze wzrostem stężenia IOA i czasem działania. Podziały komórkowe zostały zahamowane po zastosowaniu 1 lub $5 \mathrm{mM}$ IOA przez $20 \mathrm{~min}$. (zależnie od obiektu).

W badaniach nad otrzymaniem cybrydów inaktywacja jądra komórkowego przeprowadzona została za pomocą promieniowania UV, a genomu cytoplazmatycznego za pomocą IOA. Wydajność fuzji asymetrycznej zależała od jakości protoplastów po traktowaniu IOA i była wyższa, gdy obniżono do $4^{\circ} \mathrm{C}$ temp. podczas inaktywacji mitochondriów. Aktywność mitotyczna komórek po fuzji asymetrycznej była zahamowana $(2 \%) \mathrm{w}$ porównaniu $\mathrm{z}$ kontrolą (30-39\%). Przyczynę takiego stanu upatruje się w negatywnym wpływie obydwu stresów (IOA w połączeniu $\mathrm{z}$ działaniem pola elektrycznego) podczas fuzji protoplastów. Powyższe wyniki wskazują na potrzebę optymalizacji metodyki fuzji asymetrycznej uwzględniającej jednoczesne testowanie wpływu IOA oraz pola elektrycznego na jakość protoplastów i wydajność fuzji.

\section{ZADANIE 2. OPRACOWANIE MARKERÓW MOLEKULARNYCH DO OCENY STATUSU MIESZAŃCOWOŚCI REGENERANTÓW OTRZYMANYCH W WYNIKU EKSPERYMENTÓW FUZJI}

Celem tematu badawczego było określenie pochodzenia genomu jądrowego i typu cytoplazmy u regenerantów uzyskanych w wyniku fuzji protoplastów. Prowadzono także zapylenia w celu otrzymania nasion pokoleń F3 i BC1S1 do mapowania genów odporności na kiłę.

Przy zastosowaniu markerów jądrowych, które różnicowały rodziców, u żadnego $\mathrm{z}$ badanych regenerantów — produktów różnych kombinacji fuzji protoplastów nie wykazano charakteru mieszańcowego. Zastosowanie markerów cytoplazmatycznych wykazało obecność cytoplazmy normalnej (N) lub sterylizującej Ogura u badanych regenerantów.

Uzyskano kolejne pokolenia F3 i BC1S1 - po skrzyżowaniu obiektu wrażliwego i odpornego na kiłę kapusty. Otrzymane $\mathrm{z}$ tych nasion rośliny można poddać testowi odpornościowemu oraz genotypowaniu na skalę genomową, co pozwoli uzyskać informację o lokalizacji genetycznych determinant odporności na kiłę kapusty. Otrzymane pokolenia można także wykorzystać do uzyskania linii wsobnych (RIL/IBC) $\mathrm{z}$ utrwaloną zmiennością $\mathrm{W}$ zakresie odporności na kiłę. Linie tego typu pozwolą na wielokrotną (w powtórzeniach) i wieloaspektową analizę badanej cechy. 


\section{ZADANIE 3. OTRZYMYWANIE I CHARAKTERYSTYKA PODWOJONYCH HAPLOIDÓW} KAPUSTY PEKIŃSKIEJ (BRASSICA RAPA L. SUBSP. PEKINENSIS)

Badania nad roślinami DH, a następnie liniami DHR1oraz DHR2 otrzymanymi w wyniku indukcji androgenezy u kapusty pekińskiej wykazały, że indukcja androgenezy w 2016 roku zakończyła się otrzymaniem 58 roślin, które pochodziły z androgenicznych zarodków Enduro F1 i Janin F1. Adrogeniczna populacja składała się z roślin o różnej ploidalności: $59 \%$ roślin było diploidami a $41 \%$ tetraploidami. Kwiatostany roślin DH były rozwinięte prawidłowo a żywotność pyłku wahała się od 55 do 97\%. Wykonano zapylenia wsobne, aby otrzymać nasiona DHR1. 33\% zapylonych roślin DH zawiązało nasiona. W grupie roślin bez nasion przeważały formy o ploidalności $4 \times$, pomimo wysokiej żywotności pyłku. Zebrano ponad 1700 nasion DHR1. Ocena biometryczna roślin 14 linii DHR1 wykazała wyrównanie cech wewnątrz liniowe. U większości obiektów główki były kształtu cylindrycznego, średnio zwarte, półotwarte, średnia masa główki wahała się od 0,7 do $1,2 \mathrm{~kg}, \mathrm{z}$ przewagą główek o masie $0,9 \mathrm{~kg}$. Analiza markerem SSR (starter ACMP 790) wykazała homozygotyczność wszystkich badanych roślin pokoleń DHR1.

$\mathrm{Z}$ androgenezy w 2015, w 2018 wysiano nasiona 13 wyselekcjonowanych linii DHR1 w celu otrzymania pokolenia DHR2. Zakwitło 117 roślin DHR1. Żywotność pyłku była wysoka (średnia 90\%). Wykonano zapylenia wsobne i zebrano ponad 6 tys. nasion DHR2.

Z androgenezy w 2014, w 2018 oceniono 14 linii DHR2 pochodzących z mikrospor YU i Kilakin F1. Analiza biometryczna cech morfologicznych i zdrowotności wykazała bardzo wysokie wyrównanie wewnątrz badanych linii DHR2 i była zgodna z oceną ich wyjściowego pokolenia DHR1. Natomiast analiza molekularna linii DHR2 za pomocą markera SSR (starter ACMP 790) wykazała, że w przypadku 13 z 14 przebadanych linii DHR2 profil markerowy pokrywał się $\mathrm{z}$ profilem rośliny $\mathrm{DH}, \mathrm{z}$ której pochodziły i rośliny tych linii były homozygotami. Jedynie wśród roślin jednej linii obserwowano obraz świadczący o braku wyrównania genetycznego. Otrzymane wyniki wskazują, że w przypadku kapusty pekińskiej haploidyzacja pozwala na znacznie skrócenie czasu (do ok. 3 lat) potrzebnego do otrzymania homozygotycznych linii, które mogą być włączone do programów hodowlanych. 
